\title{
STRATEGI KOMUNIKASI DAKWAH MELALUI PESAN WHATSAPP GROUP DALAM MENINGKATKAN KUALITAS ILMU AGAMA
}

\author{
Muhamad Selpan Muharam Shidiq \\ Universitas Islam Negeri Sunan Gunung Djati Bandung \\ E-mail: muhamadselpan05@gmail.com
}

\begin{abstract}
Da'wah communication strategy aims to remind members and is persuasive, especially those related to daily life. Da'wah communication strategy with the aim of contemplation as well as a form of reminder. Da'wah communication is delivered in a simple and easy to understand way. Da'wah communication activities through WhatsApp group are scheduled and have the concept of Da'wah.
\end{abstract}

Keywords: Da'wah, communication, message

\begin{abstract}
Abstrak
Strategi komunikasi dakwah yang digunakan dengan tujuan untuk mengingatkan anggota dan bersifat persuasif terutama hal yang berkaitan dengan kehidupan seharihari. Strategi komunikasi dakwah dengan tujuan perenungan sekaligus sebagai bentuk pengingat. Bentuk tuturan komunikasi dakwah disampaikan dengan cara yang sederhana dan mudah dipahami. Kegiatan komunikasi dakwah melalui whatsapp group terjadwal dan memiliki konsep dakwah.
\end{abstract}

Kata Kunci : Dakwah, Pengajian, Pesan

\section{PENDAHULUAN}

Usaha untuk mendapatkan saling pengertian merupakan tujuan komunikasi melalui proses pengiriman atau penyampaian informasi dari satu pihak kepihak lain ${ }^{1}$. Aktivitas komunikasi dalam kegiatan sehari-hari memiliki tujuan pencapaian baik dalam kelompok ataupun masyarakat. Secara terminologis komunikasi merujuk pada sebuah proses penyampaian suatu pernyataan oleh seseorang kepada orang lain. Sebuah komunikasi yang efektitf dapat terjalin dengan baik jika kedua bela pihak saling mengakui kekurangan. Keberagaman dan kebebasan untuk mengakses informasi bagi pengguna tanpa harus terikat pembatasan dan sensor merupakan kelebihan dari media baru. Beragamnya informasi di internet kemudian menarik khalayak media massa untuk berpindah dari media massa lama (old media) ke media massa baru (new media). Selain itu, dengan adanya smartphone, lebih mempermudah diakses nya internet dimana saja dan kapan saja. Melalui kecanggihan tekonologi internet anda

${ }^{1}$ Ngalimun, 2017, Strategi Pembelajaran. Yogyakarta:Peranan Ilmu 
juga dapat mengakses segala jenis informasi. Tentunya hal tersebut sejalan dengan komponen pendukung komunikasi, yakni dalam mempraktekan komunikasi antar individu membutuh peralatan pendukung tertentu. Salah satunya dengan menggunakan peralatan komunikasi, seperti media sosial.

Media sosial menjadi bagian dari kehidupan komunikasi masyarakat. Sehingga, sistem kemasyarakatan menjadi bagian yang tidak terpisahkan dari sistem hukum komunikasi masyarakat. Substansi terpenting dalam mendukung komunikasi di tengah masyarakat yakni sebuah sistem pengetahuan atau ilmu pengetahuan. IImu pengetahuan juga merupakan bagian dari cara atau strategi dalam menyampaikan sebuah pendapat dalam komunikasi. Sehingga, kehadiran media sosial semata-mata membantu tatanan sosial individu dalam memeroleh informasi. Adapun hubungannya dengan proses sosial, komunikasi menjadi sebuah cara dalam melakukan perubahan sosial (socialmchange).

Komunikasi berperan sebagai jembatan dalam perbedaan antar masyarakat, karena mampu merekatkan sistem sosial masyarakat dalam usahanya melakukan perubahan. Seperti halnya yang dikemukakan oleh Little John, bahwa memahami kehidupan sosial merupakan proses dari interaksi. Struktur sosial diciptakan dan ditopang melalui interaksi. Pada penelitian ini, objek analisis terfokus pada strategi komunikasi dakwah melalui pesan whatsapp group. Dakwah adalah kegiatan yang dilakukan secara sadar dan terencana dalam usaha mempengaruhi orang lain, yakni mengajak seseorang,berbentuk lisan, tulisan, tingkah laku dan sebagainya, baik secara individual maupun secara kelompok agar timbul dalam dirinya satu pengertian, kesadaran, sikap, penghayatan serta pengamalan terhadap ajaran agama sebagai message yang disampaikan dengan tanpa adanya unsur-unsur pemaksaan.

Sehingga, komunikasi dakwah yakni proses penyampaian ajakan untuk memeroleh orang lain atau mitra tuturnya dalam kegiatan beragama ataupun memperdalam ilmu agama tanpa melalui adanya unsur pemaksaan. Berdasarkan Q.S Al-Hujurat (13) bahwasanya manusia diciptakan oleh Allah berjenis kelamin laki-laki dan perempuan, hidup secara berbangsa-bangsa dan bersuku agar saling mengenal (lita'aruf). Sehingga, perlu dilakukan adanya komunikasi. Dakwah itu telah menjadi kewajiban bagi setiap muslim, baik laki-laki ataupun perempuan. Nabi Muhammad SAW juga telah menyampaikan anjurannya bahwa "sampaikamlah diriku walau hanya satu ayat". Kegiatan komunikasi dakwah pun sudah diberi penjelasan baik dalam AlQuran ataupun Hadist Nabi SAW. Sebagaimana dalam Q.S An-Nahl (125): 
"Serulah manusia kepada jalan Tuhanmu dengan hikmah dan pelajaran yang baik dan bantahlah mereka dengan cara yang baik. Sesungguhnya Tuhanmu Dialah yang lebih mengetahui tentang siapa yang tersesat dari jalan-Nya dan Dialah yang lebih mengetahui orang-orang yang mendapat petunjuk."

Bertauhid kepada Allah merupakan ajakan utama yang terkandung dalam agama islam. Penyampaian pesan agama tersebut dilakukan dengan berbagai cara, hal ini bertujuan agar umat memahami akan pesan tersebut. Ajakan juga penuh kedamaian, rasa kasih sayang, ketentraman, dan menghindari gejolak terhadap umat. Dengan begitu, penyebaran agama Islam menjadi baik dan diterima oleh manusia. Penyebaran Islam juga melalui media sosial, film, musik yang dinilai lebih mudah dimengerti tentang apa yang disampaikan oleh juru dakwah Islam.

Penelitian tentang strategi komunikasi dakwah sudah menjadi kajian yang menarik bagi para pemerhati ilmu komunikasi dakwah atau penyiaran agama Islam. Salah satunya dilakukan oleh Amien Wibowo (2015) dengan judul penelitian strategi komunikasi dakwah (startegi komunikasi dakwah majelis dzikir dan sholawat Jamuro Surakarta) adapun hasil penelitiannya berupa strategi komunikasi yang digunakan². Target yang ingin dicapai yakni umat Islam pada khususnya, dan masyarakat Kota Solo pada umumnya. Pendekatan yang digunakan bermacam-macam, yakni secara langsung, melalui media cetak dan elektronik. Mempertahankan budaya membaca tahlilan, dan pembacaan sholawat merupakan tujuan dakhwah yang coba di sampaikan komunikator tertentu, yakni tim dakwah yang sangat mengerti dan paham dakwah Islam yang dilakukan Jamuro.

Berdasarkan penelitian terdahulu tersebut peneliti hendak menganalisis tentang strategi komunikasi dakwah dalam upaya meningkatkan kualitas ilmu agama Islam. Menurut Arifin, nilai hakiki pendidikan tercermin dari tujuan pendidikan itu sendiri. Diperlukan rumusan sistem dan tujuan yang baik dalam pendidikan Islam. ${ }^{3}$ Dinamika yang dialami pendidikan Islam akan seirama dengan kepentingan dan perkembangan masyarakat bila ditinjau dari aspek historis.

Fenomena menarik yang menjadi indikator dalam penelitian ini yakni, strategi komunikasi yang disampaikan melalui media sosial. Media sosial menjadi wadah atau alat dalam menyampaikan pesan atau ilmu, khususnya dakwah dengan tujuan meningkatkan kualitas ilmu agama. Sebagaimana dalam penelitian terdahulu yang menganalisis tentang strategi komunikasi dakwah melalui media sosial dilakukan oleh

\footnotetext{
${ }^{2}$ Wibowo, Amien. (2015). Strategi Komunikasi Dakwah (Strategi Komunikasi Dakwah Majelis Dzikir dan Sholawat Jamuro Surakarta. SKRIPSI. Universitas Muhammadiyah Surakarta. Surakarta

${ }^{3}$ Fuad, Ah. Zakki. 2014. Taksonomi Transeden (Paradigma Baru Tujuan Pendidikan Islam). Jurnal Pendidikan Islam. Vol. 02 No. 1 Mei 2014.
}

Vol. 3, No. 1, Juni 2020, pp 29-38

Muhamad

Strategi Komunikasi Dakwah Melalui Pesan... 
Imas Mutiawati ${ }^{4}$ dengan judul penelitian Dakwah Media Sosial (Studi Fenemonologis Dakwah Di Instagram). Adapun hasil penelitian yang diperoleh bahwa media dakwah berkembang sampai ke media sosial instagram. Hal tersebut terlihat dengan semakin marak nya penggunaan media sosial sebagai wadah berdakwah, contohnya banyak da'i yang bermunculan dan mengalih fungsikan akun media sosial instagram pribadi sebagai media untuk berdakwah. Hal ini dipicu oleh banyaknya generasi milenial yang gemar menggunakan Instagram daripada media sosial lainya,hal ini kemudian menjadi peluangpara da'i untuk menggunakan media sosial instagram yang impactnya mampu membuat viral suatu konten. Kedua, terkait bentuk metode dakwah bil lisan, bil hal, dan bil qalam di instagram dapat di uraikan sebagai berikut: (1) Dakwah bil lisan jika diterapkan pada instagram yaitu melakukan siaran langsung ceramah atau pengajian dengan menggunakan fitur instagram live, menggunggah konten video dakwah menggunakan fitur instagram TV dan instagram video, melakukan diskusi atau tanya jawab pada fitur instagram direct (direct message). (2) Bentuk metode dakwah bilhal pada instagram yaitu dengan mengalihfungsikan akun instagram pribadi menjadi media untuk berdakwah, selain itu, memaksiamlkan fitur yang terdapat di intagram, yakni fitur instagram foto dan instagram story untuk publikasi kegiatan amal. (3) Bentuk metode dakwah bil lisan di instagram terealisasi denganpenulisan konten-konten yang mengandung dakwah dengan memaksimalkan fitur caption pada unggahan instagram dan instagram story.

Berlatar fenomena media sosial yang dijadikan sebagai alat melakukan strategi dakwah terlebih sasaran utama adalah generasi milenial. Maka, peneliti juga melakukan analisis penelitian tentang strategi komunikasi dakwah melalui pesan whatsapp group dalam upaya meningkatkan kualitas ilmu agama Islam pada kelompok ibu-ibu pengajian Majlis Taklim Al-Anshoriyah Kabupaten Cianjur. Objek penelitian yakni kelompok bu-ibu pengajian Majlis Taklim Al-Anshoriyah Kabupaten Cianjur dipilih karena merupakan salah satu kelompok pengajian yang aktif dalam menyiarkan dan mempelajari ilmu agama Islam baik secara online maupun offline. Kelompok pengajian ini juga memanfaatkan media whatsapp group sebagai sarana dakwah dalam meningkatkan kualitas ilmu agama. Sehingga pada penelitian ini hendak mengetahui bagaimana bentuk strategi komunikasi dakwah yang digunakan? Dan bagaimana keefektifitas strategi dakwah tersebut dalam meningkatkan kualitas ilmu agama?

\footnotetext{
${ }^{4}$ Mutiawati, Imas. 2018. Dakwah Media Sosial (Studi Fenomenologi Dakwah Di Instagram). Skripsi UIN Wali Songo. Semarang.
} 


\section{PEMBAHASAN}

Islam disebut sebagai agama dakwah, karena dakwah dinilai sebagai ciri khas dari agama Islam. yakni agama yang disebarluaskan dengan cara damai, tanpa lewat kekerasan. Dalam sejarahnya, Islam juga memiliki masa peperangan pada zaman Nabi Muhammad SAW dan sahabat, namun peperangan itu bermaksud mempertahankan dan melepaskan masyarakat dari penindasan penguasa tirani.Nabi Muhammad Saw semasa hidup juga tidak pernah memaksa penduduk yang daerahnya tertundukkan saat peranguntuk memeluk Islam. (Aziz, 2004: 1) dalam Mutiawati ${ }^{5}$.

Dakwah bertujuan untuk mencapai tujuan tertentu, dengan cara melakukan serangkaian kegiatan atau proses. Sehingga tercipta arahan atau pedoman umat untuk melaksanakan kegiatan dakwah yang di maksud. Sehingga dengan dakwah, dapat terwujud masyarakat Islam yang kaffah, yaitu masyarakat yang menjalankan ajaran Islam secara komprehensif, dan benar, serta mampumengikuti tantangan zaman. Yakni Da'i menyampaikan materi dakwah dengan tujuan individu, kelompok, atau masyarakat mampu menelaah dan menerima pesan dakwah yang dimaksud, yakni denga menggunakan metode dakwah. Ceramah, tausiyah, nasihat, diskusi, uswah, bimbingan konseling, atau qudwahhasanah merupakan beberapa metode atau strategi yang telah diguanakan oleh para da'i (Amin, 2009:13). ${ }^{6}$

Media sosial merupakan bagian dari sistem relasi, koneksi dan komunikasi. Menurut Buku Panduan Optimalisasi Media Sosial Untuk Kementrian Perdagangan RI terkait dengan peran dan manfaat media sosial adalah media sosial dapat dimanfaatkan untuk belajar data dan isu yang termuat di dalamnya, yakni dengan, mendengarkan dan menyampaikan berbagai aplikasi melalui beragam informasi. Selain itu, menyampaikan informasi kepada pihak lain merupakan keunggulan dari media sosial. Konten-konten di dalam media sosial berasal dari berbagai belahan dunia dengan beragam latar belakang budaya, sosial, ekonomi, keyakinan, tradisi dan tendensi. Oleh karena itu, dapat dikatakan benar,jika dalam arti positif, media sosial adalah sebuah ensiklopedi global yang tumbuh dengan cepat. Namun dalam konteks ini, bekal pemikiran kritis, emosi yang terkontrol dan analisis yang lebih tajam, serta perenungan mendalam, dirasa harus dimiliki oleh setiap pengguna media sosial.

\footnotetext{
${ }^{5}$ Mutiawati, Imas. 2018. Dakwah Media Sosial (Studi Fenomenologi Dakwah Di Instagram). Skripsi UIN Wali Songo. Semarang.

${ }^{6}$ Amin, Samsul Munir. Ilmu Dakwah. 2009. Jakarta : AMZAH.
}

Vol. 3, No. 1, Juni 2020, pp 29-38 
Media internet memiliki karakter broadcast, sementara karakter interactivity mewakili media baru yang dapat melampaui pola penyebaran pesan atau informasi dengan media tradisional, karena media internet memiliki sifat yaitu bisa berinteraksi, mengaburkan batas geografis, dan bisa dilakukan kapan saja. Salah satu karakter yang disebut sebgai media atau media baru ${ }^{7}$.

Whatsapp menjadi salah satu media sosial yang sudah tidak asing lagi di kalangan masyarakat modern. Berbagai lapisan masyarakat mulai dari remaja hingga dewasa memanfaatkan media whatsapp sebagai sarana untuk berkomunikasi. Kini fungsi whatsapp tidak hanya sebagai sarana komunikasi, namun juga menjadi media wadah bertukar informasi. Salah satu kelompok pengajian Majlis Taklim Al-Anshoriyah Kabupaten Cianjur memanfaatkan fitur whatsapp yakni pesan group menjadi sarana penyiaran agama Islam. Berdakwah pada whatsapp group kelompok pengajian BKMM Pagelaran memfokuskan pada strategi komunikasi dakwah seperti:

\section{a. Tujuan Komunikasi yang Disampaikan}

Whatsapp group dengan judul Kajian IImu dan Dakwah tersebut memiliki tujuan utama yakni menyiarkan agama Islam serta belajar lebih dalam ilmu agama Islam dengan tujuan untuk meningkatkan kualitas Iman. Pesan komunikasi yang disampaikan pun ringan sehingga anggota group tersebut dapat menyimak dan mudah memahami isi pesan. Sebagaimana contoh pesan Whatsapp dari salah seorang anggota dibawah ini:

\section{Data 1. Komunikasi Anak dan Ayah}

Ada seorang anak yang setiap hari rajin sholat ke mesjid, lalu suatu hari ia berkata kepada ayahnya, "Ayah mulai hari ini saya tidak mau ke mesjid lagi," Kemudian sang ayah bertanya "loh kenapa?". Sang anak pun menjawab "Karena dimesjid saya menemukan orang-orang yang kelihatannya agamais tapi sebenarnya tidak, ada yang sibuk dengan hpnya, sementara yang lain membicarakan keburukan orang lain." Sang ayah pun berfikir sejenak dan berkata "Baiklah kalau begitu, tapi ada satu syarat yang harus kamu lakukan setelah itu terserah kamu."

Berdasarkan data (1) di atas tujuan komunikasi pesan dakwahnya adalah untuk mengajak anggota grup untuk tidak berpeliaku tidak baik seperti membeicarakan keburukan orang lain dan sibuk menggunakn handphone ketika sedang dalam

\footnotetext{
${ }^{7}$ Nasrullah, 2014, Teori dan Riset dan media siber (Cyibermedia) Jakarta: Kencana Premadamedia
} Grup. 
melaksanakan kewajiban yang telah Allah tetapkan kepada hamba Nya. Tujuan pengirim pesan ini untuk mengingatkan semua anggota grup agar tidak terjerumus kedalam hal yang tidak baik seperti membicarakan keburukan orang lain dan mengunakan handphone didalam melaksanakan kewajiban dirumah Allah SWT. Data (1) menunjukkan strategi komunikasi dakwah dengan maksud mengingatkan dan bersifat persuasif. Isi contoh dakwah yang disampaikan pun masih berkaitan dengan keadaan sehari-hari. Sehingga anggota dapat mudah memahami maksud dakwah dan pesan tersampaikan dengan baik.

\section{Data 2. Pemilihan Kata}

"Jangan ucapkan ok ucapkan insyallah, jangan ucapkan hebat ucapakan masyaallah, jangan ucapkan saya baik-baik saja ucapkan alhamdulilah, jangan ucapkan terimakasih ucapkan jazakallahu khairan, jangan ucapkan hat-hati ya sampai jumpa ucapkan fii aminillah."

Pada data (2) tersebut menunjukkan bahwa strategi komunikasi dakwah yang digunakan bermaksud untuk menambah istilah baru yang sesuai dengan ajaran agama Islam. Pesan tersebut disampaikan untuk mengajak agar setiap ucapan yang dikeluarkan dari mulut digantikan dengan ucapan doa supaya perkataan yang dikeluarkan lebih indah atau baik didengar misalnya "wow digantikan dengan Subhanaallah".

\section{Data 3. Sabda Nabi}

"Nabi shallallahu alaihi wasallam bersabda niscaya aku akan melihat beberapa kaum dari umatku datang pada hari kiamat dengan kebaikan laksana gunung-gunung Tihamah yang putih, kemudia Allah Azza wa jalla menjadikannya debu yang berterbangan. Ada yang bertanya: wahai Rasulullah, jelaskanlah sifat mereka kepada kami, agar kami tidak menjadi bagian dari mereka sementara kami tidak tahu. Nabi Shallallahu alaihi wa sallam menjawab: ketahuilah, mereka adalah saudara kalian, satu bangsa, dan bangun malam sebagaimana kalian. Tapi jika mereka menyendiri dengan larangan-larangan Allah, mereka melanggarnya."

Adapun pesan data (3) pada whatsapp group tersebut menerapkan strategi komunikasi dakwah agar anggota pengajian senantiasa merenungkan agar mempunyai rasa takut kepada sang maha pencipta langit dan bumi Allah swt. Seperti yang disebutkan dalam pesan ini "takutlah kepada Allah dalam keadaan tersembunyi dan nampak". Tujuan dari pengirim pesan agar anggota grub memiliki rasa takut 
kepada Allah swt dalam berbuat suatu kejahatan ataupun ketika berada dalam keadaan apapun yang dianggap tidak baik untuk dilakukan.

\section{b. Bentuk Tuturan Komunikasi}

Sebagaimana yang disajikan pada data penelitian diatas dapat dianalisis bahwa strategi tuturan komunikasi dakwah yang dilakukan menggunakan bahasa yang sederhana dan mudah untuk dipahami. Sehingga, anggota baru yang baru bergabung dengan grup pengajian BKMM Pagelarandapat mengikuti dengan mudah topik yang disampaikan. Komunikasi dengan menggunakan bahasa yang sederhana memang dibutuhkan dalam menyampaikan pesan kepada mitra tutur.

\section{c. Penggunaan Media Whatsapp Group}

Adapun proses komunikasi dakwah pada grup pengajian BKMM Pagelaran dilakukan setiap hari Jum'at. Sehingga komunikasi dakwah yang dilakukan terstruktur sesuai dengan jadwal. Dakwah melalui media yang dinilai cukup efektif serta mampu di gunakan dimana saja dan kapanpun adalah dakwah melaluiwhatsapp group, disamping itu whatsapp groupjuga relatif murah namun menjangkau khalayak yang banyak.Dan tentunya melalui whatsapp group pesan dakwah dapat disampaikan sesuai dengan topik kajian dan terfokus pada sasaran anggota yang sudah bergabung.

\section{SIMPULAN}

Berdasarkan analisis dan pembahasan penelitian strategi somunikasi dakwah melalui pesan whatsapp group dalam meningkatkan kualitas ilmu agama dalam pengajian Majlis Taklim Al-Anshoriyah kabupaten cianjur yakni:

1. Strategi komuhikasi dakwah dengan tujuan untuk mengingatkan anggota dan bersifat persuasif.

2. Strategi komunikasi dakwah dengan tujuan untuk menambah istilah baru dalam ilmu agama terutama hal yang berkaitan dengan kehidupan sehari-hari.

3. Strategi komunikasi dakwah dengan tujuan perenungan sekaligus sebagai bentuk pengingat.

4. Bentuk tuturan komunikasi dakwah disampaikan dengan cara yang sederhana dan mudah dipahami.

5. Kegiatan komunikasi dakwah melaluiwhatsapp group terjadwal dan memiliki konsep dakwah. 


\section{DAFTAR PUSTAKA}

Amin, Samsul Munir. Ilmu Dakwah. 2009. Jakarta : Amzah.

Arifin. 2000. Strategi Belajar Mengajar. Jurusan Pendidikan Kimia FPMIPA UPI. Bandung.

Fuad, Ah. Zakki. 2014. Taksonomi Transeden (Paradigma Baru Tujuan Pendidikan Islam). Jurnal Pendidikan Islam. Vol. 02 No. 1 Mei 2014.

Muhlis. 2016. Dakwah di Media Sosial (Studi Fenomenologi Aktifitas Dakwah di Facebook). Tesis. Tidak Dipublikasikan. Universitas Islam Negari Alaudin.

Mutiawati, Imas. 2018. Dakwah Media Sosial (Studi Fenomenologi Dakwah Di Instagram). Skripsi. UIN Wali Songo. Semarang.

Nasrullah, 2014, Teori dan Riset dan media siber (Cyibermedia) Jakarta: Kencana Premadamedia Grup.

Ngalimun, 2017, Strategi Pembelajaran. Yogyakarta:Peranan IImu

Saputra, Wahidin. 2011. Pengantar Ilmu Dakwah. Jakarta: PT. RajaGrafindo Persada

Sugiyono. (2016). Metode Penelitian Kuantitatif, Kualitatif dan R\&D. Bandung: PT Alfabet.

Wibowo, Amien. (2015). Strategi Komunikasi Dakwah (Strategi Komunikasi Dakwah Majelis Dzikir dan Sholawat Jamuro Surakarta. Skripsi. Universitas Muhammadiyah Surakarta. Surakarta 
HALAMAN INI SENGAJA DIKOSONGKAN

Vol. 3, No. 1, Juni 2020, pp 29-38

Muhamad

Strategi Komunikasi Dakwah Melalui Pesan... 